\title{
Geochemical Control on Uranium(IV) Mobility in a Mining-Impacted Wetland
}

\author{
Yuheng Wang, ${ }^{\dagger}$ Alexandre Bagnoud, ${ }^{\dagger}$ Elena Suvorova, ${ }^{\dagger}$ Eric McGivney, ${ }^{\dagger}$ Lydie Chesaux, ${ }^{\dagger}$ \\ Vannapha Phrommavanh, ${ }^{\ddagger}$ Michael Descostes, ${ }^{\ddagger}$ and Rizlan Bernier-Latmani ${ }^{*}, \dagger$ \\ ${ }^{\dagger}$ Ecole Polytechnique Fédérale de Lausanne (EPFL) - Environmental Microbiology Laboratory (EML) EPFL-ENAC-IIE-EML, \\ Station 6, CH-1015 Lausanne, Switzerland \\ ${ }^{\ddagger}$ AREVA - Business Group Mines, R\&D Department, BAL 0414C-2, Tour AREVA, 1, place Jean Millier, 92084 Paris La Défense \\ Cedex, France
}

\section{Supporting Information}

ABSTRACT: Wetlands often act as sinks for uranium and other trace elements. Our previous work at a mining-impacted wetland in France showed that a labile noncrystalline U(IV) species consisting of $\mathrm{U}(\mathrm{IV})$ bound to $\mathrm{Al}-\mathrm{P}-\mathrm{Fe}-\mathrm{Si}$ aggregates was predominant in the soil at locations exhibiting a Ucontaining clay-rich layer within the top $30 \mathrm{~cm}$. Additionally, in the porewater, the association of U(IV) with $\mathrm{Fe}(\mathrm{II})$ and organic matter colloids significantly increased U(IV) mobility in the wetland. In the present study, within the same wetland, we further demonstrate that the speciation of $U$ at a location not impacted by the clay-rich layer is a different noncrystalline $\mathrm{U}(\mathrm{IV})$ species, consisting of U(IV) bound to organic matter in soil. We also show that the clay-poor location includes an abundant sulfate supply and active microbial sulfate reduction that induce substantial pyrite $\left(\mathrm{FeS}_{2}\right)$ precipitation. As a result, $\mathrm{Fe}(\mathrm{II})$ concentrations in the porewater are much lower than those at clay-impacted zones. U porewater concentrations $(0.02-0.26 \mu \mathrm{M})$ are also considerably lower than those at the clay-impacted locations $(0.21-3.4 \mu \mathrm{M})$ resulting in minimal $U$ mobility. In both cases, soil-associated $U$ represents more than $99 \%$ of $U$ in the wetland. We conclude that the low $\mathrm{U}$ mobility reported at clay-poor locations is due to the limited association of Fe(II) with organic matter colloids in porewater and/or higher stability of the noncrystalline U(IV) species in soil at those locations.

\section{INTRODUCTION}

Uranium is a radioactive heavy metal element widely distributed in Earth's continental crust and for which wetlands often act as natural sinks accumulating concentrations of up to ten thousand parts per million ( $\mathrm{ppm}, \mathrm{mg} / \mathrm{kg}$ of dry matter). For instance, the United States Geological Survey reported that the top $15 \% \mathrm{U}$ concentrations found in peat from the investigated natural wetlands in the Front Range of Colorado state (United States) are comparable to those in commercially mined lowgrade $U$ ores $(\sim 1,000 \mathrm{ppm}){ }^{1}$ They also found a maximum $U$ level of 10,000 ppm detected in woody peat and organic rich sediments at the Flodelle Creek natural wetland (Washington State, United States). ${ }^{2}$ Regenspurg et al. discovered concentrations of uranium up to $4,000 \mathrm{ppm}$ in a natural organic-rich soil in the Dischma valley, ${ }^{3}$ an alpine region in Switzerland. All of the areas in which these types of natural $U$ accumulation were identified are in mountainous regions and underlain by granites or rhyolitic volcanic rocks that are commonly uraniferous. Additionally, $\mathrm{U}$ can also accumulate in wetlands due to anthropogenic activity. For example, Schöner et al. reported a $U$ content of up to 7,500 ppm within peat horizons in wetlands of the Thuringia and Saxony regions in Germany contaminated by seepage from adjacent tailings of former $\mathrm{U}$ mills. $^{4}$

Uranium immobilization in wetland soils is believed to involve sorption onto $\mathrm{Fe}$ - and Mn-oxyhydroxides as well as organic matter. ${ }^{5}$ Moreover, reductive precipitation of sparingly soluble $\mathrm{U}(\mathrm{IV})$ minerals such as uraninite $\left(\mathrm{U}^{\mathrm{IV}} \mathrm{O}_{2}\right)$ could occur under the reducing conditions that prevail in anoxic sediments and wetland soils. The formation of $\mathrm{U}^{\mathrm{IV}} \mathrm{O}_{2}$ as a result of microbially mediated reduction of mobile uranyl ions $\left(\mathrm{U}^{\mathrm{VI}} \mathrm{O}_{2}{ }^{2+}\right)^{6}$ is considered an efficient process for $\mathrm{U}$ immobilization. ${ }^{7}$ Hence, constructed wetland systems are targeted as an immobilization strategy for U-contaminated water. ${ }^{8-10}$ However, noncrystalline $\mathrm{U}(\mathrm{IV})$ species were recently discovered as a product of microbial U(VI) reduction in laboratory tests ${ }^{11-14}$ and field experiments. ${ }^{15}$ These noncrystalline species are commonly referred to as "monomeric U(IV)" in reference to the absence of $\mathrm{U}-\mathrm{U}$ pair correlations in their X-ray absorption spectroscopy (XAS) spectra. ${ }^{11,16}$ It is generally accepted that U

Received: April 1, 2014

Revised: July 22, 2014

Accepted: July 22, 2014 

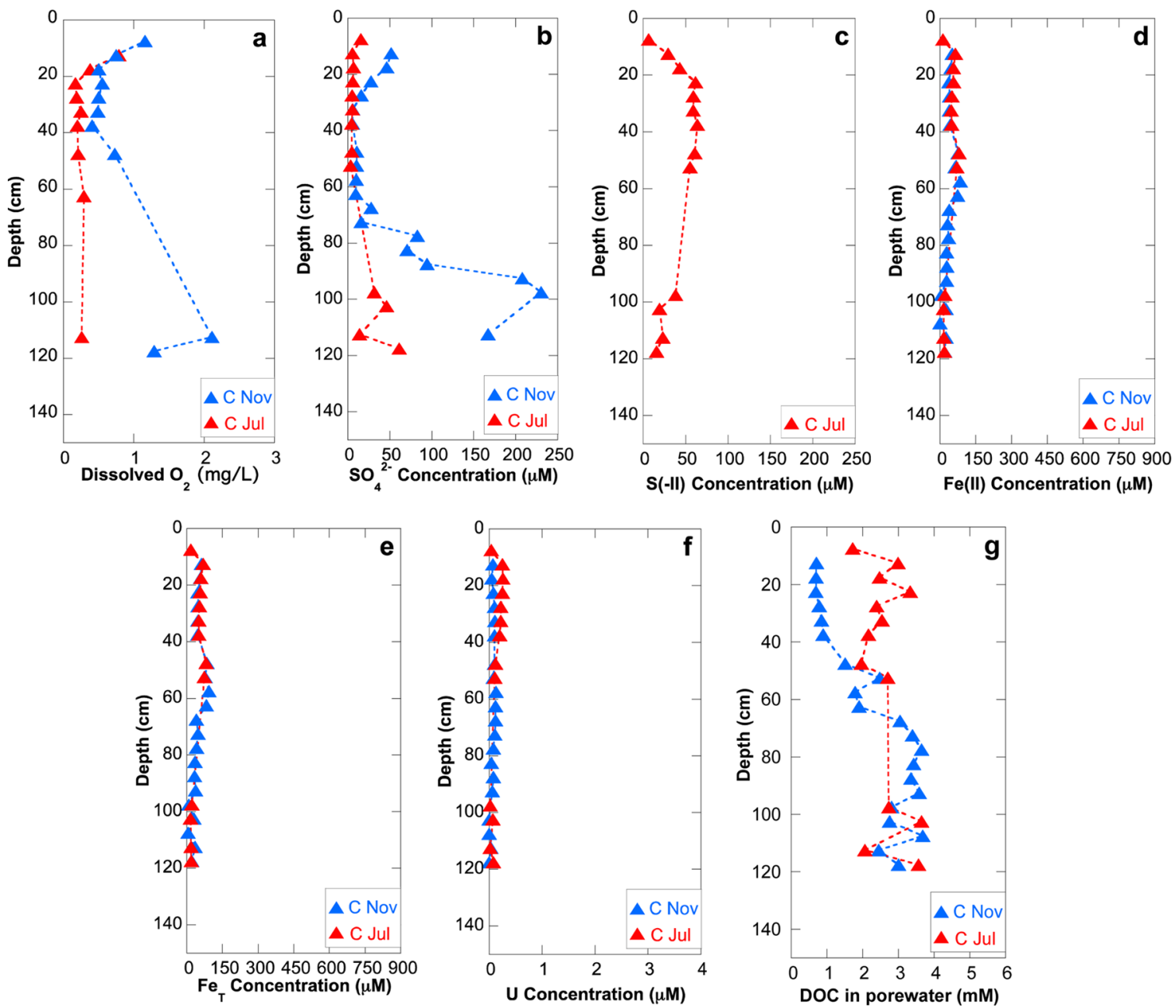

Figure 1. Porewater profiles of (a) DO, (b) $\mathrm{SO}_{4}{ }^{2-}$, (c) S(-II), (d) $\mathrm{Fe}(\mathrm{II})$, (e) $\mathrm{Fe}_{\text {Total }}$ (f) U, and (g) DOC at spot C in November 2011 and July 2012. The porewater $\mathrm{pH}$ value is $5.5 \pm 0.2$ in both seasons. The measured porewater temperature is $7-10^{\circ} \mathrm{C}$ and $17-22^{\circ} \mathrm{C}$ in November and July, respectively. The standard deviation $(\delta)$ is less than $5 \%$ of the reported values based on three replicate measurements and is not shown.

atoms are bound to phosphate groups in organic or mineral substrates in the monomeric U(IV) species identified to date but this may not be the only type of coordination in the environment. A recent study further showed that monomeric $\mathrm{U}(\mathrm{IV})$ species are more susceptible to oxidation than uraninite. $^{17}$

In our recent field study at a mining-impacted wetland in France, we demonstrated that a labile monomeric U(IV)-like species (noncrystalline $\mathrm{U}(\mathrm{IV})$ bound to $\mathrm{Al}-\mathrm{P}-\mathrm{Fe}-\mathrm{Si}$ amorphous aggregates) was predominant in a U-bearing clay-rich layer within the top $30 \mathrm{~cm}$ of the soil. ${ }^{18}$ The lability of this $\mathrm{U}(\mathrm{IV})$ species resulted in the association of U(IV) with $\mathrm{Fe}(\mathrm{II})$ and organic matter colloids in the porewater, which significantly increased U(IV) mobility in the wetland, even though more than $99 \%$ of $U$ in the wetland is associated with soil. Additionally, we showed that the U-bearing clay-rich layer originates from an overflow area of the former settling pond of the adjacent mining site. ${ }^{18}$ Indeed, similar U(VI)-bearing Ferich particulate $\mathrm{Si}$ gels were found in a $\mathrm{U}$ mining drainage in the same Massif Central region. ${ }^{19}$

Nonetheless, a significant question remains: what geochemical parameters control the mobility of U(IV)-bearing colloids? The goal of the present study was to identify critical controls on U(IV) mobility by considering an area of the same wetland that does not include the above-mentioned clay layer.

\section{MATERIALS AND METHODS}

Site Description. The site was described in a previous related publication, ${ }^{18}$ and a site map is included in the Supporting Information (Figure S1) of the present article. In the previous study, spots A and B were primarily considered. Here, we compare and contrast those spots with spot C. Spot C shows no visible clay layer in the depth range of $0-50 \mathrm{~cm}$, whereas spots $\mathrm{A}$ and $\mathrm{B}$ display distinct clay layers in the depth ranges of $10-25 \mathrm{~cm}$ and $10-30 \mathrm{~cm}$, respectively.

Sampling and Analysis. The soil and core samples in the present study were collected and conditioned on site under anoxic conditions in November 2011 and July 2012. The core was sampled under a high-flow Ar stream, sealed in airtight bags, conditioned in an anoxic chamber $\left(\mathrm{N}_{2}\right.$ atmosphere $) 5 \mathrm{~min}$ away from the sampling spots, and then transported back to EPFL in sealed MYLAR bags. The porewater was sampled with a vertical resolution of $5 \mathrm{~cm}$ using multichambered piezometers designed and manufactured at EPFL. ${ }^{18}$ The porewater was collected under an Ar stream, sealed in serum bottles with blue butyl rubber stoppers, handled in an anoxic chamber $\left(\mathrm{N}_{2}\right.$ atmosphere) $5 \mathrm{~min}$ away from the sampling spots, and then transported back to EPFL in sealed serum bottles. X-ray diffraction (XRD), scanning electron microscopy (SEM), transmission electron microscopy (TEM), and XAS analyses 
were carried out under anoxic conditions. The details of Fe(II), $\mathrm{S}(-\mathrm{II})$, metal ion, anion, and dissolved organic carbon (DOC) analyses are included in the Supporting Information.

TEM observation of both colloids in porewater samples and U-bearing aggregates in soil samples was conducted using either an FEI Tecnai Osiris microscope at $200 \mathrm{kV}$ or an FEI CM300UT/FEG microscope at $300 \mathrm{kV}$ at EPFL. Soil total organic carbon (TOC) content was measured in dried homogenized samples with a Shimadzu TOC-V CPH/CPN analyzer. To study the soil chemical composition and $U$ content (Figure S4, Supporting Information), soil samples were dissolved completely using a three-step $\mathrm{HNO}_{3} / \mathrm{HF}$ microwave digestion procedure with a high performance microwave (Microwave Laboratory Systems) and then analyzed using inductively coupled plasma-optical emission spectroscopy (ICP-OES). XRD analysis was conducted under anoxic conditions with Co $\mathrm{K} \alpha$ (wavelength $=1.79 \AA$ ) radiation on a Panalytical X'Pert Pro MPD diffractometer at Institut de Minéralogie et de Physique de Milieux Condensés (IMPMC) in Paris. SEM observation of soil samples was conducted using a Carl Zeiss Merlin microscope with GEMINI II column at 1 $\mathrm{kV}$ and $100 \mathrm{pA}$ at EPFL. Uranium $\mathrm{L}_{\mathrm{III}^{-}}$-edge $(17.166 \mathrm{keV}) \mathrm{X}$-ray absorption near-edge structure (XANES) and extended X-ray absorption fine structure (EXAFS) data were obtained at the Core EXAFS beamline (B18) of Diamond Light Source (DLS) and Rossendorf Beamline (BM20) of the European Synchrotron Radiation Facility (ESRF), respectively. Pyrosequencing was performed on soil samples collected for selected samples at spots B and C. Detailed method descriptions are presented in the Supporting Information.

Microbial Community Analysis. Pyrosequencing was performed on soil samples collected in November 2011 at three depths at spots B and C. The depths analyzed at spot B were: (a) $0-5 \mathrm{~cm}$, (b) $20-25 \mathrm{~cm}$, and (c) $100-105 \mathrm{~cm}$. The depths analyzed at spot $C$ were: (a) $0-15 \mathrm{~cm}$, (b) $20-25 \mathrm{~cm}$, and (c) 100-105 cm. DNA from soil samples was extracted with a previously established DNA extraction protocol. ${ }^{15}$ Following DNA extraction from soil samples, the 16S rRNA gene was amplified using $8 \mathrm{f}$ and $518 \mathrm{r}$ primers. The amplicons were sent to a facility (Research and Testing Laboratory in Lubbock TX, USA) for 454 pyrosequencing. The analysis of the DNA sequences was carried out with MacQIIME (qiime.org) for denoising, and the removal of chimeric sequences was carried out using chimera.slayer command (http://www.mothur.org/wiki/Chimera.slayer) implemented in MacQIIME. More detail is available in the Supporting Information.

\section{RESULTS}

Porewater Chemistry. Selected porewater profiles of dissolved oxygen (DO), $\mathrm{SO}_{4}{ }^{2-}, \mathrm{S}(-\mathrm{II}), \mathrm{Fe}(\mathrm{II}), \mathrm{Fe}_{\text {total }}, \mathrm{U}$, and DOC of spot C in November 2011 and in July 2012 are presented in Figure 1. To facilitate comparison, data for spots A and B from the previous study ${ }^{18}$ are available in Figure S2, Supporting Information. The porewater $\mathrm{pH}$ value is at $5.5 \pm 0.2$ at spot $\mathrm{C}$, compared to $5.8 \pm 0.2$ at spots $\mathrm{A}$ and $\mathrm{B}$ in both seasons. Dissolved organic carbon (DOC) values are comparable at spot $\mathrm{C}(2 \pm 1 \mathrm{mM}$ in July $2012,2.7 \pm 0.6$ $\mathrm{mM}$ in November 2011) relative to spots $\mathrm{A}(1.2 \pm 0.2 \mathrm{mM}$ in November 2011, $2.7 \pm 0.4 \mathrm{mM}$ in July 2012) and B $(2.1 \pm 0.7$ $\mathrm{mM}$ in November 2011, $3 \pm 2 \mathrm{mM}$ in July 2012). The DO profiles show a decreasing pattern at depths from 10 to $30 \mathrm{~cm}$ and become stable below $30 \mathrm{~cm}$, from suboxic to anoxic values.
Spot C shows lower DO values than spots A and B in both seasons, except a spike near the bottom of the profile, and the DO profiles in July 2012 of all three spots show lower concentrations than their respective profiles in November 2011. These results suggest more reducing conditions at all three spots in July 2012 than in November 2011. At spot C, a decrease in sulfate concentration from 10 to $30 \mathrm{~cm}$ and enhanced sulfate reduction in July 2012 can be observed. A similar sulfate reduction pattern is also found at spot A, albeit with an average sulfide concentration $(4 \pm 1 \mu \mathrm{M})$ ten times lower than that at spot $\mathrm{C}(41 \pm 20 \mu \mathrm{M})$. The significant sulfate concentrations at $80-120 \mathrm{~cm}$ at spot $C$ in November 2011 and corresponding low sulfide and high DO at that depth are attributable to presumed inflow of sulfate- and DO-bearing groundwater at that season. At all three spots, Fe(II) concentration represents the entirety of $\mathrm{Fe}$ in the porewater, suggesting active $\mathrm{Fe}(\mathrm{III})$ reduction. At spot $\mathrm{C}, \mathrm{Fe}(\mathrm{II})$ concentrations in porewater are about ten times lower than those at spots $\mathrm{A}$ and $\mathrm{B}$ with an average of $39 \pm 22 \mu \mathrm{M}$ in November 2011 and $43 \pm 23 \mu \mathrm{M}$ in July 2012 . With $\sim 10$ times lower $\mathrm{Fe}(\mathrm{II})$ and $\sim 10$ times higher sulfide concentrations at spot $\mathrm{C}$, it is expected that iron sulfide precipitation would occur at this location. Altogether, evidence for microbial iron- and sulfate-reduction is an indicator that reducing conditions prevail throughout the soil profile with seasonal deviations of the redox front in the top $30 \mathrm{~cm}$. Most interestingly, $\mathrm{U}$ content in the porewater is low at spot $\mathrm{C}$ with $0.07 \pm 0.07 \mu \mathrm{M}$ in November 2011 and $0.14 \pm 0.09 \mu \mathrm{M}$ in July 2012, compared to an average $\mathrm{U}$ concentration of $0.79 \pm 0.17 \mu \mathrm{M}$ in November 2011 and $0.91 \pm 0.07 \mu \mathrm{M}$ in July 2012 at spot $\mathrm{A}$ and up to $3 \mu \mathrm{M}$ in November 2011 at spot B, namely, concentrations about ten times higher than those at spot $\mathrm{C}$.

Porewater Colloids. The porewater sample collected at $20-25 \mathrm{~cm}$ depth at spot $\mathrm{C}$ in November 2011 was characterized using scanning transmission electron microscopy (STEM). The results show that more than $90 \%$ of the colloids in the sample from spot $C$ are irregular in shape, whereas those in the spot A sample systematically display a beads-on-a-string morphology (Figure 2a,c). Energy dispersive X-ray spectroscopy (EDS) elemental mapping shows that colloids at spot $\mathrm{C}$ are rich in carbon but poor in iron ( $\mathrm{Fe}$ signal is similar to background from the silicon nitride TEM window). In contrast, spot A colloids contain both iron and carbon (Figure 2d), as previously demonstrated by Wang et al. ${ }^{18}$ Moreover, point EDS analyses reveal the absence of a $U$ signal and very low iron signal in the colloids at spot $\mathrm{C}$ (Figure $2 \mathrm{~b}$ ) while the colloids at spot A show low but statistically relevant $U$ concentrations in association with iron and carbon (Figure 2d). Overall, this suggests that, while both locations display OM-rich colloids in the porewater, the $\mathrm{Fe}(\mathrm{OH})_{2}$ nanoparticles and associated $\mathrm{U}$ found at spot $\mathrm{A}^{18}$ are mostly absent from colloids at spot $\mathrm{C}$.

Soil Chemistry and Mineralogy. Soil chemical composition profiles were obtained from selected samples. Water content, TOC, $\mathrm{Si}, \mathrm{Al}, \mathrm{Fe}$, and $\mathrm{U}$ profiles of spot $\mathrm{C}$ are presented in Figure S3, Supporting Information. To facilitate comparison, data from spots A and B from the previous study ${ }^{18}$ are also shown in Figure S4, Supporting Information. Soil samples from spot $\mathrm{C}$ are rich in water $(75 \%-90 \% \mathrm{w} / \mathrm{w}$ in the top $100 \mathrm{~cm})$, similarly to those from spots A and B. Total organic carbon (TOC) content $(w / w)$ in dry soil shows significantly higher values at spot $C$ (average value of $38 \% \pm 10 \%$ ) compared to both spot A (average value of $16 \% \pm 8 \%$ ) and spot $\mathrm{B}$ (average value of $21 \% \pm 6 \%)$. Si and $\mathrm{Al}$ contents $(\mathrm{w} / \mathrm{w})$ for the first 30 

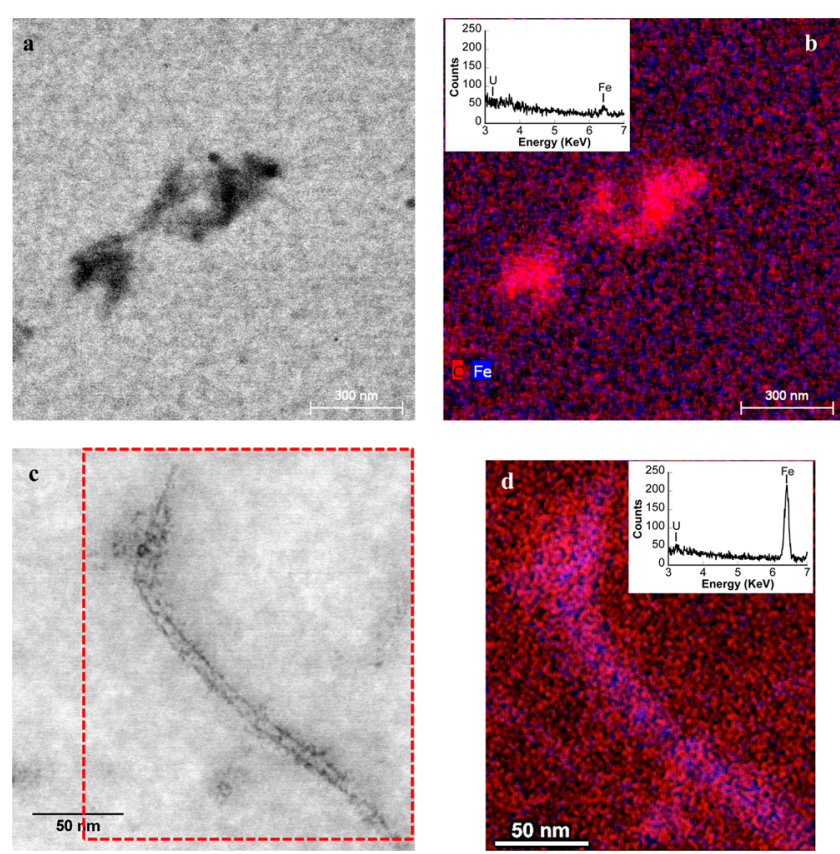

Figure 2. (a) STEM image of typical colloid particles from porewater collected at $20-25 \mathrm{~cm}$ depth at spot $\mathrm{C}$ in November; 37 out of the 40 analyzed colloid particles at spot $\mathrm{C}$ show a similar morphology. (b) The corresponding $\mathrm{Fe}$ (blue)/C (red) EDS map and the inset showing nondetectable $\mathrm{U}$ signal and low Fe signal in a typical EDS spectrum obtained from the colloid particles at spot C. (c) STEM image of typical colloid particles from porewater collected at $15-20 \mathrm{~cm}$ depth at spot A in November; the analyzed colloid particles at spot A systematically show a similar morphology. (d) The iron (blue)/carbon (red) EDS map corresponding to the zone marked by a red dashed rectangle in (c) and the inset showing low $\mathrm{U}$ signal and high Fe signal in a typical EDS spectrum obtained from the colloid particles at spot A.

$\mathrm{cm}$ are significantly lower at spot $\mathrm{C}(\mathrm{Si}=6 \% \pm 4 \%, \mathrm{Al}=0.5 \%$ $\pm 0.1 \%$ ) than those at both spot A (average concentrations: $\mathrm{Si}$ $=12 \% \pm 2 \%, \mathrm{Al}=2.0 \% \pm 0.2 \%)$ and spot $\mathrm{B}(\mathrm{Si}=10 \% \pm 3 \%$, $\mathrm{Al}=1.8 \% \pm 0.3 \%)$. These results suggest lower clay mineral content at spot $\mathrm{C}$ than at spots $\mathrm{A}$ and $\mathrm{B}$. Indeed, images of the cores (Figure S4a, Supporting Information) show the presence of a distinct clay-rich layer at $10-25 \mathrm{~cm}$ for spot A and at $10-$
$30 \mathrm{~cm}$ for spot $\mathrm{B}$ but the absence of this layer at spot C. Moreover, XRD analysis confirmed that spot $\mathrm{C}$ diffractograms at $0-30 \mathrm{~cm}$ displayed little clay mineral and high humic matter content (Figure S5c, Supporting Information), whereas muscovite, smectite, albite, orthoclase, and kaolinite as well as quartz are found at spots A and B (Figure S5a,b, Supporting Information), as presented by Wang et al. ${ }^{18}$ These data, along with $\mathrm{Al}$ and $\mathrm{Si}$ profiles, underscore the minimal content of aluminosilicates at spot $\mathrm{C}$ as compared to spots $\mathrm{A}$ and $\mathrm{B}$. Moreover, $\mathrm{XRD}$ analysis evidence the precipitation of pyrite $\left(\mathrm{FeS}_{2}\right)$ at $20-40 \mathrm{~cm}$ at spot $\mathrm{C}$ and at $30-40 \mathrm{~cm}$ at spot $\mathrm{B}$. This finding is also borne out in soil Fe content measurements. At spot $\mathrm{C}$, a spike in $\mathrm{Fe}$ concentration $(2.9 \% \pm 0.2 \%)$ corresponding to pyrite precipitation is found at $20-40 \mathrm{~cm}$; however, the $\mathrm{Fe}$ content at $0-20 \mathrm{~cm}(0.6 \%-0.8 \%)$ is much lower than that at spots A and B $(2.1 \%-3.5 \%)$. On the basis of these results, schemes summarizing the known soil layers and precipitation of pyrite for spot $C$ are shown in Figure S4b, Supporting Information, along with the same information for spots $\mathrm{A}$ and $\mathrm{B}$.

At spot $\mathrm{C}$, the $\mathrm{U}$ soil profile shows high $\mathrm{U}$ concentrations $(700-1,600 \mathrm{ppm})$ solely at shallow depths $(0-30 \mathrm{~cm})$ as compared to low $U$ concentrations $(40-120 \mathrm{ppm})$ in the soil below. Soil-associated U represents more than $99 \%$ of $U$ in the wetland. A similar phenomenon was observed at spots A and B, where the high $U$ zone corresponds to the above-mentioned clay-rich layer and immediately adjacent depths, and this layer is the source of $U$ at these two locations. ${ }^{18}$ Moreover, for spot $\mathrm{C}$, no correlation could be found between the high $\mathrm{U}$ zone and the occurrence of any mineralogical phase (Figure S4b, Supporting Information), suggesting $U$ association to organic matter rather than minerals in the soil at this spot.

Uranium Speciation in the Soil. To identify the Ubearing phase in the soil at spot C, SEM and TEM analyses were conducted on the sample at $20-25 \mathrm{~cm}$ (Figure S6, Supporting Information). We identified amorphous aggregates several microns in size in this sample as well as polygon-shaped Fe- and S-rich particles, which could be pyrite, the only iron sulfide mineral found in the XRD pattern of the sample. Repeated TEM-EDS analyses show that $\mathrm{U}$ is only detectable in association with the amorphous aggregates (Table S1, Supporting Information) and not on pyrite particles (data not shown). Compared to the $\mathrm{Al}-\mathrm{P}-\mathrm{Fe}-\mathrm{Si}$ aggregates at spot
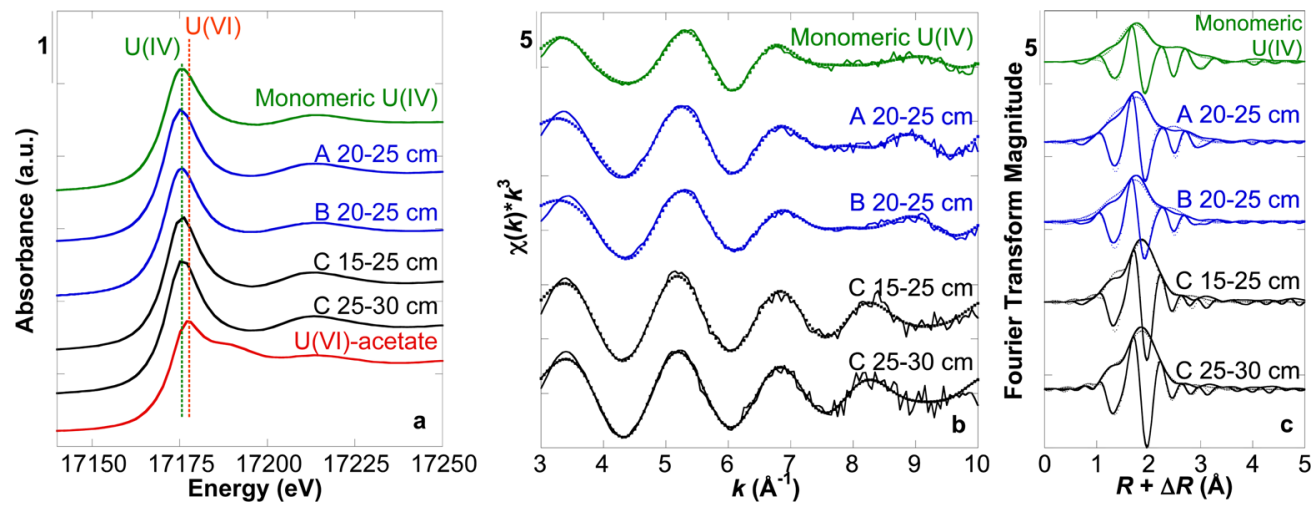

Figure 3. Uranium $\mathrm{L}_{\mathrm{III}}$-edge data recorded for the soil samples at spot $\mathrm{C}$ at $15-25 \mathrm{~cm}$ and $25-30 \mathrm{~cm}$ compared to selected monomeric $\mathrm{U}$ (IV)-like soil samples at spot $A$ at $20-25 \mathrm{~cm}$ and at spot B at $20-25 \mathrm{~cm}$ and monomeric U(IV) and U(VI)-acetate model compounds. (a) XANES data showing that $\mathrm{U}(\mathrm{IV})$ is the predominant valence state in all soil samples; (b) unfiltered $k^{3}$-weighted EXAFS data; (c) magnitude and imaginary part of the Fourier transform (FT). Experimental and calculated curves (see Table S3, Supporting Information, for parameters) are displayed as solid and dashed lines, respectively. The data of spots $\mathrm{A}$ and $\mathrm{B}$ are replotted from Wang et al. ${ }^{18}$ 
A (Table S2, Supporting Information), the aggregates at spot C are much richer in $\mathrm{C}, \mathrm{N}$, and $\mathrm{S}$ and poorer in $\mathrm{Al}, \mathrm{P}$, and $\mathrm{Fe}$. Indeed, the sum of the atomic percentages of $\mathrm{C}, \mathrm{N}, \mathrm{S}$, and $\mathrm{O}$ is $91 \% \pm 2 \%$, suggesting that the $\mathrm{U}$-containing aggregates at spot $\mathrm{C}$ consist mostly of organic matter (OM).

$\mathrm{U}$ valence and coordination states were investigated by $\mathrm{U}$ $\mathrm{L}_{\mathrm{III}}$-edge X-ray absorption spectroscopy (XAS) on two soil samples at $15-30 \mathrm{~cm}$ at spot $\mathrm{C}$ and compared to model compounds and to samples from spots A and B (Figure 3). Xray absorption near-edge structure (XANES) spectra (Figure 3a) exhibit an absorption maximum at $17,175.0 \mathrm{eV}$ for all samples, underscoring the predominantly tetravalent oxidation state of $U$ in the soil, which is consistent with the metal reducing conditions evidenced by the presence of $\mathrm{Fe}$ (II) in the porewater. The predominance of U(IV) is confirmed by the results of linear combination fitting using "monomeric U(IV)" and "U(VI) acetate" reference spectra as fitting components (Table S3, Supporting Information). Oscillations from unfiltered and $k^{3}$-weighted extended X-ray absorption fine structure (EXAFS) spectra collected for soil samples at spot C differ from those of a monomeric U(IV) model compound or two selected samples from spots A and B, suggesting a different U-binding environment (Figure 3b). Table S4, Supporting Information, lists the results of the shell-by-shell fitting parameters of unfiltered EXAFS data. First-neighbor contributions were fit with $10 \pm 2 \mathrm{O}$ atoms at $2.13 \pm 0.03$ and $2.33 \pm$ $0.03 \AA$. These coordination numbers are slightly higher than those of $\mathrm{U}(\mathrm{IV})$ in uraninite $^{20}$ or monomeric-U(IV)-like species $^{11,12,14}$ and close to those of U(IV) coordinated with carbonate. ${ }^{21}$ Second-neighbor contributions were fit with $5 \mathrm{C}$ atoms at $2.88 \pm 0.03 \AA$, suggesting that $U(I V)$ in the soil samples at spot $\mathrm{C}$ is likely bound to carboxylic groups. Thus, the fits confirm the absence of a $U-U$ pair typical of $U(I V)$ minerals such as uraninite ${ }^{20}$ and the absence of a U-P pair typical of monomeric-U(IV)-like species. ${ }^{11,12,14}$

Microbial Analysis. Pyrosequencing was performed on soil samples collected from three depths at spots B and C in November 2011. The full data are presented in Figure S7 and Table S5, Supporting Information. As expected in a soil, the microbial community includes significant functional as well as phylogenetic diversity. The array of bacterial phyla identified mainly consists of Proteobacteria including $\alpha$-, $\beta$-, $\gamma$-, and $\delta$ proteobacteria classes, Chloroflexi with Dehalococcoidetes and Anaerolineae classes, Firmicutes with the Clostridia class, and Nitrospirae with the Nitrospira class. It is observable that the contribution of the phylum Proteobacteria to the overall population decreases with depth while that of Chloroflexi increases with depth.

At the shallowest depth $(0-5 \mathrm{~cm})$ at spot $\mathrm{B}, \mathrm{N}_{2}$-fixing microorganisms such as Bradyrhizobium spp., ${ }^{22}$ denitrifying microbes such as members of the order Burkholderiales ${ }^{23}$ or the genus Rhodoplanes ${ }^{24}$ are observed. They occur to a lesser extent at spot C. Additionally, members of the family Methylophilaceae, methylotrophs able to oxidize methanol but not methane with oxygen, ${ }^{25}$ are found at spot $\mathrm{B}$ at the shallowest depth $(0-5 \mathrm{~cm})$ and within the clay layer $(20-25$ $\mathrm{cm}$ ), suggesting that traces of $\mathrm{O}_{2}$ remain at those depths (as is borne out in the DO profile of November 2011 at spot B). In comparison, there is minimal contribution from methylotrophs at spot $\mathrm{C}$, consistent with much lower DO values at this location. Four metabolic groups more directly relevant to this study are identified: iron-reducing bacteria, iron-oxidizing bacteria, sulfate-reducing bacteria, and organic matter-degrading bacteria (Figure 4).

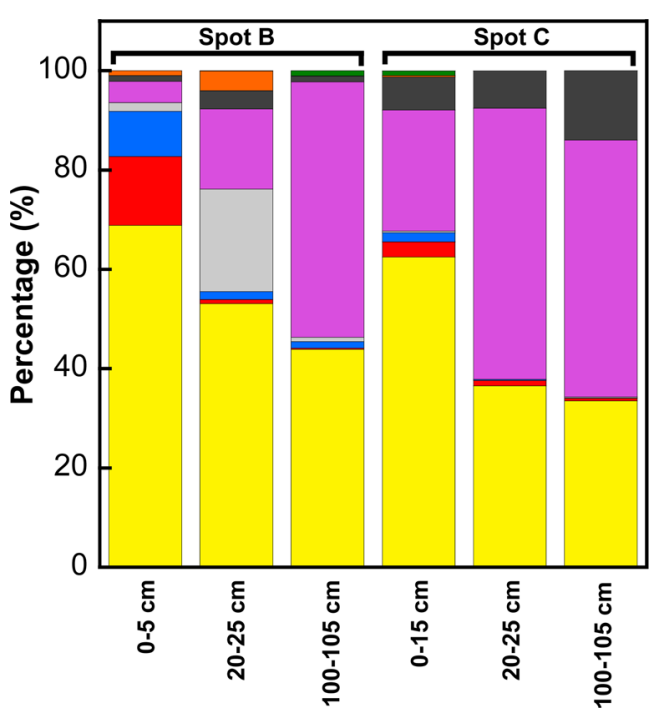

Figure 4. Results of microbial analysis of $16 \mathrm{~S}$ rRNA for selected samples at spots B and C summarized in function of known metabolism. Green: metal-reducing bacteria (Geobacter and Clostridium); orange: metal-oxidizing bacteria (Crenothrix); black: sulfatereducing bacteria (Desulfobacca and Thermodesulfovibrionaceae); purple: anaerobic OM-respiring bacteria (Anaerolineae and Dehalococcoidetes); gray: methylotrophic bacteria (Methylophilaceae and Methylosinus); blue: $\mathrm{N}_{2}$-fixing bacteria (Bradyrhizobium); red: denitrifying bacteria (Burkholderiales and Rhodoplanes); yellow: others.

Sequences of the $16 \mathrm{~S}$ rRNA gene belonging to representatives of a genus of known iron-reducing bacteria are detected in some samples (Figure 4). Indeed, Geobacter spp. represents $0.07 \%, 0.42 \%$, and $0.92 \%$ of the microbial community at $0-5$ $\mathrm{cm}$ and $20-25 \mathrm{~cm}$ at spot $\mathrm{B}$ and at $0-15 \mathrm{~cm}$ at spot $\mathrm{C}$, respectively. Additionally, Clostridium spp., known to reduce $\mathrm{Fe}(\mathrm{III})$ through fermentation ${ }^{26}$ or respiration, ${ }^{27}$ is also found at $100-105 \mathrm{~cm}$ at spot B $(0.61 \%)$. Moreover, iron-oxidizing bacteria from the Crenothrix genus ${ }^{28}$ are identified in samples from spot B at $0-5 \mathrm{~cm}(1.4 \%)$ and at $20-25 \mathrm{~cm}(3.95 \%)$ and from spot $C$ at $0-15 \mathrm{~cm}(0.33 \%)$ (Figure 4$)$. This suggests iron redox cycling at both locations.

Sulfate-reducing bacteria were identified in all samples at spot $B$ and spot C (Figure 4). Members of the Thermodesulfovibrionaceae family were detected at all depths at both locations, with a higher contribution at spot $\mathrm{C}$ than spot $\mathrm{B}$. Most of the members of this family were described as thermophilic sulfatereducing bacteria, but some were found to live in mesophilic environments such as marine coastal sediments. ${ }^{29}$ Additionally, sulfate-reducing bacteria stemming from the Desulfobacca genus (in the Syntrophaceae family) are present at all depths, but their contribution increases with depth and is greater at spot $\mathrm{C}$ than at spot B.

Finally, fermenting bacteria, anaerobic OM respiring bacteria, and the syntrophs take a prominent part of the overall community at the deeper locations (Figure 4). The Dehalococcoidetes and Anaerolinaceae classes within the Chloroflexi phylum, known for respiring organic compounds including halogenated substrates, ${ }^{30,31}$ occupy an increasing proportion of the total population with depth and higher proportion at spot $\mathrm{C}$ than at spot $\mathrm{B}$ at the same depth (except 

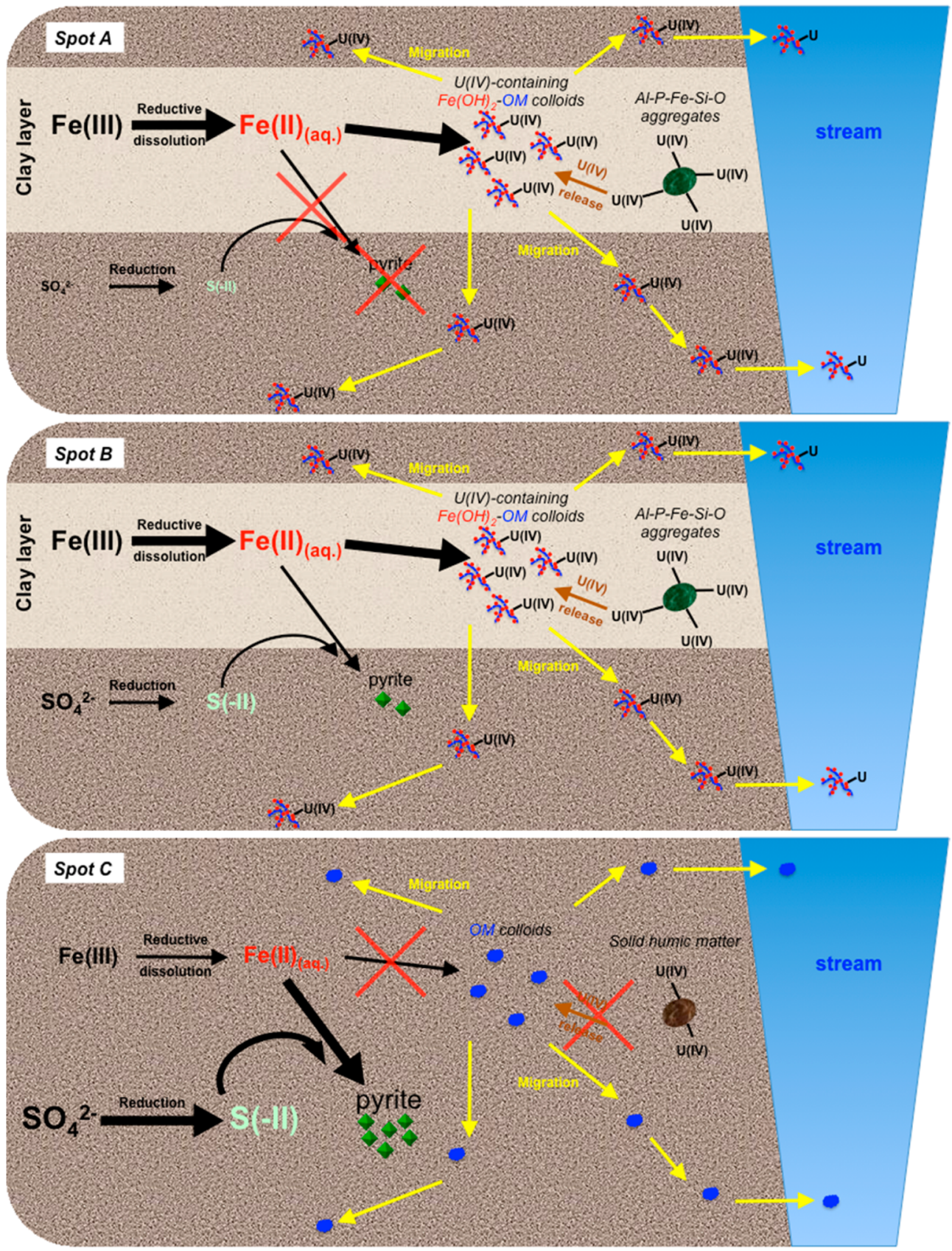

Figure 5. Schemes showing the processes and components in soil that control $U$ speciation and mobility for the depth of $0-50 \mathrm{~cm}$ at spots $\mathrm{A}, \mathrm{B}$, and C. At spot $\mathrm{A}$, the $\mathrm{U}$-rich clay layer is present and the $\mathrm{Al}-\mathrm{P}-\mathrm{Fe}-\mathrm{Si}-\mathrm{O}$ aggregates include $\mathrm{U}$, and active Fe reduction combined with low sulfate supply result in no pyrite precipitation but high porewater $\mathrm{Fe}$ (II). Combination of $\mathrm{Fe}$ (II) with DOM promotes the formation of beads-on-a-string colloids, responsible for U(IV) mobilization. At spot B, the sulfate supply is higher and pyrite precipitation is observed, but porewater Fe(II) is still high and beads-on-a-string colloids are present. At spot $\mathrm{C}$, the U-rich clay layer is absent and $\mathrm{U}$ is bound to solid humic matter. The supply of sulfate is abundant resulting in pyrite precipitation, low porewater $\mathrm{Fe}(\mathrm{II})$, and $\mathrm{Fe}(\mathrm{II})$-poor colloids of irregular shape to which little $\mathrm{U}(\mathrm{IV})$ is associated.

Anaerolinaceae that is low at $100-105 \mathrm{~cm}$ at spot C). These distributions are consistent with the higher organic matter content at spot $\mathrm{C}$ than at spot $\mathrm{B}$ and the presumed inflow of sulfate- and DO-bearing groundwater in November 2011 at $100-105 \mathrm{~cm}$ at spot C, evidenced by the sulfate and DO porewater profiles at this location.

\section{DISCUSSION}

Microbial Iron and Sulfate Reduction. The analytical results of porewater and soil analyses at the three spots suggest the occurrence of $\mathrm{Fe}(\mathrm{III})$ and $\mathrm{SO}_{4}{ }^{2-}$ reduction. Sulfate-reducing bacteria (i.e, Desulfobacca and Thermodesulfovibrionaceae) and microorganisms potentially capable of iron and uranium reduction (e.g., Geobacter and Clostridium) are detected, supporting the microbial origin of $\mathrm{SO}_{4}{ }^{2-}$ and $\mathrm{Fe}$ reduction. At spot $\mathrm{A}, \mathrm{Fe}(\mathrm{II})$ concentrations are high and $\mathrm{S}(-\mathrm{II})$ concentrations are low in the porewater while no pyrite is detected in the soil. At spot B, high $\mathrm{Fe}$ (II) and low S(-II) concentrations were detected in the porewater and the presence of pyrite in the soil was evidenced in an OM-rich layer. At spot $\mathrm{C}$, low $\mathrm{Fe}$ (II) and high S(-II) concentrations were observed in the porewater and the presence of abundant pyrite 
in the soil was identified. These results seem to suggest a decreasing trend in iron reduction activity at spots $\mathrm{A}, \mathrm{B}$, and $\mathrm{C}$ along with an increasing trend in sulfate reduction activity. This progression is likely due to the relative iron and sulfate content at the various spots. At spot A, the soil is Fe-rich and the porewater is sulfate-poor. At spot B, the soil is Fe-rich and the porewater displays an intermediate sulfate concentration. Finally, at spot $\mathrm{C}$, the soil is Fe-poor and OM-rich and the porewater is rich in $\mathrm{SO}_{4}{ }^{2-}$ due to presumed input from groundwater.

It is interesting to note the strongly increasing trend of the contribution of Chloroflexi (Dehalococcoidaceae and Anaerolinaceae families) with increasing depth. This is expected, as these organisms are typically associated with the breakdown of organic matter under anoxic conditions. Archaea were not probed, but we would expect methanogenesis to prevail in these environments, especially with low sulfate concentrations.

Geochemical Control on $U$ Speciation and Mobility. Laboratory studies have previously demonstrated that U(VI) bioreduction could yield noncrystalline U(IV) species that are characterized by $\mathrm{U}(\mathrm{IV})$ association with phosphate groups in biomass in batch and column systems. ${ }^{11-13}$ XAS and EM data from the present study and our previous work ${ }^{18}$ show that $\mathrm{U}(\mathrm{IV})$ in the soil at spots $\mathrm{A}$ and $\mathrm{B}$ is bound to phosphate groups in amorphous $\mathrm{Al}-\mathrm{P}-\mathrm{Fe}-\mathrm{Si}$ aggregates to form monomeric U(IV)-like species. In contrast, U(IV) in the soil at spot $\mathrm{C}$ is bound to amorphous $\mathrm{OM}$ aggregates likely through carboxylic groups; thus, a noncrystalline form of U(IV) distinct from the phosphate-bound U(IV) species is found at spots A and $\mathrm{B}$. This is consistent with the fact that the soil at spot $\mathrm{C}$ is rich in $\mathrm{OM}$ and poor in $\mathrm{Fe}$. Altogether, these results suggest that $\mathrm{U}$ speciation in the wetland soil is controlled by the OM and $\mathrm{Fe}$ content.

Our previous study has shown evidence of the association of $\mathrm{U}(\mathrm{IV})$ with mobile $\mathrm{Fe}(\mathrm{OH})_{2}$-OM colloids in porewater at spot $A$, which are implicated in the release of $U$ to the stream flowing through the wetland resulting in a $U$ concentration up to $0.13 \mu \mathrm{M}$. $^{18}$ In the present study, TEM observations of porewater at spot $\mathrm{C}$ show that it also contains colloids but they are OM-rich and Fe-poor as compared to those at spots $\mathrm{A}$ and B. This is consistent with the fact that the porewater DOC values at spot $C$ are comparable to those at spots $A$ and $B$, while the porewater $\mathrm{Fe}(\mathrm{II})$ concentrations are $\sim 10$-fold lower. The paucity of $\mathrm{Fe}$ (II) associated with OM colloids could lead to (1) a different morphology of the colloids and (2) the absence of $\mathrm{Fe}(\mathrm{OH})_{2}$ nanoparticles on the colloids, which could result in a decrease in affinity of the colloids for $U$ through an unknown mechanism.

In summary, pyrite precipitation promoted by higher S(-II) derived from the active microbial reduction of the sulfate, together with the relatively low Fe present in the soil at spot $\mathrm{C}$, results in lower $\mathrm{Fe}$ (II) concentration in porewater. In turn, the low $\mathrm{Fe}$ (II) concentration decreases the affinity of $\mathrm{U}$ to OM-rich colloids relative to $\mathrm{Fe}$ (II)-bearing $\mathrm{OM}$ colloids.

An additional explanation for lower $\mathrm{U}$ mobility at spot $\mathrm{C}$ as compared to spots A and B may be the higher stability of the $\mathrm{U}(\mathrm{IV})$-bearing solid phase at spot C. At spot C, U(IV) is present as part of the amorphous OM aggregates and may be less labile than $\mathrm{U}(\mathrm{IV})$ associated with phosphate in the amorphous $\mathrm{Al}-\mathrm{P}-\mathrm{Fe}-\mathrm{Si}$ aggregates at spots $\mathrm{A}$ and $\mathrm{B}$. Thus, overall, the lower $U$ mobility at the mineral-poor location (spot C) could probably be due to lower Fe(II) content in porewater colloids and/or higher stability of the noncrystalline U(IV) species in soil. Both of these factors are derived from the low $\mathrm{Fe}$ content and high sulfate supply at this location. A model summarizing the mechanism controlling $U$ speciation and mobility at spots A, B, and C is shown in Figure 5. Moreover, the proposed model is also consistent with the findings in a previous study ${ }^{4}$ that reported elevated uranium content (up to $4,000 \mathrm{ppm}$ ) in a natural organic-rich soil at Dischma Valley in Switzerland and relatively limited $U$ concentration in porewater (mostly lower than $0.1 \mu \mathrm{M}$ ), probably also because of the low Fe content in both soil (120-140 ppm) and porewater (mostly $20-40 \mu \mathrm{M})$.

Implications for Use of Wetlands in U Immobilization. Using constructed wetland systems as a filter was proposed as an immobilization strategy for uranium-contaminated water. $^{8-10}$ The efficiency of uranium removal was reported to depend on geochemical parameters such as temperature, $\mathrm{pH}$, the concentrations of chloride, nitrate, sulfate, ammonium, and toxic heavy metals, ${ }^{8}$ as well as hydraulic parameters such as retention time, effluent flow, water depth, aspect ratio, and shape. ${ }^{9}$ The results of the present study, together with those of our previous work, ${ }^{18}$ show that uranium stability and mobility in wetlands may also be controlled by the speciation of the uranium-bearing phase(s) in soil and porewater, which are, in turn, controlled by geochemical parameters, specifically the local abundance of iron and sulfate and the mineral content in the soil.

Our findings show that, under the anoxic conditions prevalent within wetland soils, uranium is mainly in the $\mathrm{U}(\mathrm{IV})$ valence state. Iron- and sulfate-reducing bacteria actively produce $\mathrm{Fe}(\mathrm{II})$ and $\mathrm{S}(-\mathrm{II})$, that precipitate to form insoluble iron sulfides. If the quantity of $\mathrm{Fe}(\mathrm{II})$ produced exceeds the stoichiometry needed for quantitative precipitation with $\mathrm{S}(-\mathrm{II})$, $\mathrm{Fe}$ (II) will be available to associate with mobile organic matter colloids in the porewater. These iron-rich colloids enhance uranium mobility as U(IV) associates readily with them. Conversely, if S(-II) exceeds the stoichiometry needed for quantitative precipitation with $\mathrm{Fe}(\mathrm{II})$, the latter is sequestered within the sulfides and there is little $\mathrm{Fe}$ (II) available to associate with mobile organic matter colloids, resulting in limited uranium mobility. Consequently, when using wetlands as uranium filters, the relative abundance of iron and sulfate is a controlling parameter for $\mathrm{U}$ removal efficiency. Lowering $\mathrm{Fe}$ (II) concentrations in the porewater by supplying sulfate into wetlands is a possible way to maintain low uranium mobility. Moreover, our results suggest that low iron content in soil favors the association of U(IV) with organic matter aggregates in soil, which may be less labile than the $\mathrm{U}(\mathrm{IV})-\mathrm{Al}-\mathrm{P}-\mathrm{Fe}-\mathrm{Si}$ aggregates found in a mineral-rich layer within the wetland. Consequently, wetlands containing a higher amount of iron due to natural and/or anthropological processes of mineral input may be inefficient when used for $U$ remediation, even when reducing conditions are ensured.

\section{ASSOCIATED CONTENT}

\section{Supporting Information}

Additional data and all experimental details. This material is available free of charge via the Internet at http://pubs.acs.org.

\section{AUTHOR INFORMATION}

\section{Corresponding Author}

*E-mail: rizlan.bernier-latmani@epfl.ch. 


\section{Notes}

The authors declare no competing financial interest.

\section{ACKNOWLEDGMENTS}

We thank Manon Frutschi (EPFL), Leia Falquet (EPFL), Justine Gay-des-Combes (EPFL), Jérémy Nos (AREVA), and Hélène de Boissezon (AREVA) for their assistance in sampling campaigns, Pierre Rossi (EPFL) for help with DNA extraction, Elena Rossel (EPFL) for help with IC, DOC, and TOC analyses, Marco Cantoni (EPFL) and Emad Oveisi (EPFL) for help with TEM observation, CEAL of EPFL for analytical support, and CIME of EPFL for electron microscopy support. The anoxic XRD experiments were carried out at IMPMC, Paris, France. We are grateful to G. Morin and L. Delbes for their assistance in planning XRD experiments. The XAS experiments were performed on the BM20 beamline at the European Synchrotron Radiation Facility (ESRF), Grenoble, France, and B18 beamline at Diamond Light Source, Oxfordshire, UK. We are indebted to A. Scheinost and A. Rossberg from ESRF and A. Dent and S. Parry from Diamond for their assistance in XAS data acquisition. Financial support of this research from AREVA is gratefully acknowledged.

\section{REFERENCES}

(1) Owen, D. E.; Otton, J. K.; Hills, F. A.; Schumann, R. R. Uranium and other elements in Colorado Rocky Mountain wetlands; a reconnaissance study; U.S. Government Printing Office: Washington, DC, 1992.

(2) Owen, D. E.; Otton, J. K. Mountain Wetlands - Efficient Uranium Filters - Potential Impacts. Ecol. Eng. 1995, 5, 77-93.

(3) Regenspurg, S.; Margot-Roquier, C.; Harfouche, M.; Froidevaux, P.; Steinmann, P.; Junier, P.; Bernier-Latmani, R. Speciation of naturally-accumulated uranium in an organic-rich soil of an alpine region (Switzerland). Geochim. Cosmochim. Acta 2010, 74, 2082-2098.

(4) Schöner, A.; Noubactep, C.; Büchel, G.; Sauter, M. Geochemistry of natural wetlands in former uranium milling sites (eastern Germany) and implications for uranium retention. Chem. Erde - Geochem. 2009, 69 (Supplement 2), 91-107.

(5) Grybos, M.; Davranche, M.; Gruau, G.; Petitjean, P. Is trace metal release in wetland soils controlled by organic matter mobility or $\mathrm{Fe}-$ oxyhydroxides reduction? J. Colloid Interface Sci. 2007, 314, 490-501.

(6) Lovley, D. R.; Phillips, E. J. P.; Gorby, Y. A.; Landa, E. R. Microbial reduction of uranium. Nature 1991, 350, 413-416.

(7) Bargar, J. R.; Bernier-Latmani, R.; Giammar, D. E.; Tebo, B. M. Biogenic uraninite nanoparticles and their importance for uranium remediation. Elements 2008, 4, 407-412.

(8) Groudev, S. N.; Bratcova, S. G.; Komnitsas, K. Treatment of waters polluted with radioactive elements and heavy metals by means of a laboratory passive system. Miner. Eng. 1999, 12, 261-270.

(9) Groza, N.; Manescu, A.; Panturu, E.; Filcenco-Olteanu, A.; Panturu, R. I.; Jinescu, C. Uranium wastewater treatment using wetland system. Rev. Chim. 2010, 61, 680-684.

(10) Winde, F. Peatlands as filters for polluted mine water?-A case study from an uranium-contaminated karst system in South AfricaPart II: Examples from literature and a conceptual filter model. Water 2011, 3, 323-355.

(11) Bernier-Latmani, R.; Veeramani, H.; Vecchia, E. D.; Junier, P.; Lezama-Pacheco, J. S.; Suvorova, E. I.; Sharp, J. O.; Wigginton, N. S.; Bargar, J. R. Non-uraninite products of microbial U(VI) reduction. Environ. Sci. Technol. 2010, 44, 9456-9462.

(12) Fletcher, K. E.; Boyanov, M. I.; Thomas, S. H.; Wu, Q. Z.; Kemner, K. M.; Loffler, F. E. U(VI) reduction to mononuclear U(IV) by desulfitobacterium species. Environ. Sci. Technol. 2010, 44, 47054709.

(13) Sharp, J. O.; Lezama-Pacheco, J. S.; Schofield, E. J.; Junier, P.; Ulrich, K.-U.; Chinni, S.; Veeramani, H.; Margot-Roquier, C.; Webb, S.
M.; Tebo, B. M.; Giammar, D. E.; Bargar, J. R.; Bernier-Latmani, R. Uranium speciation and stability after reductive immobilization in aquifer sediments. Geochim. Cosmochim. Acta 2011, 75, 6497-6510.

(14) Veeramani, H.; Alessi, D. S.; Suvorova, E. I.; Lezama-Pacheco, J. S.; Stubbs, J. E.; Sharp, J. O.; Dippon, U.; Kappler, A.; Bargar, J. R.; Bernier-Latmani, R. Products of abiotic U(VI) reduction by biogenic magnetite and vivianite. Geochim. Cosmochim. Acta 2011, 75, 25122528.

(15) Bargar, J. R.; Williams, K. H.; Campbell, K. M.; Long, P. E.; Stubbs, J. E.; Suvorova, E. I.; Lezama-Pacheco, J. S.; Alessi, D. S.; Stylo, M.; Webb, S. M.; Davis, J. A.; Giammar, D. E.; Blue, L. Y.; BernierLatmani, R. Uranium redox transition pathways in acetate-amended sediments. Proc. Natl. Acad. Sci. U.S.A. 2013, 110, 4506-4511.

(16) Senko, J. M.; Kelly, S. D.; Dohnalkova, A. C.; McDonough, J. T.; Kemner, K. M.; Burgos, W. D. The effect of U(VI) bioreduction kinetics on subsequent reoxidation of biogenic U(IV). Geochim. Cosmochim. Acta 2007, 71, 4644-4654.

(17) Cerrato, J. M.; Ashner, M. N.; Alessi, D. S.; Lezama-Pacheco, J. S.; Bernier-Latmani, R.; Bargar, J. R.; Giammar, D. E. Relative reactivity of biogenic and chemogenic uraninite and biogenic noncrystalline U(IV). Environ. Sci. Technol. 2013, 47, 9756-9763.

(18) Wang, Y.; Frutschi, M.; Suvorova, E.; Phrommavanh, V.; Descostes, M.; Geipel, G.; Bernier-Latmani, R. Mobile uranium(IV)bearing colloids in a mining-impacted wetland. Nat. Commun. 2013, 4, 2942.

(19) Allard, T.; Ildefonse, P.; Beaucaire, C.; Calas, G. Structural chemistry of uranium associated with $\mathrm{Si}, \mathrm{Al}, \mathrm{Fe}$ gels in a granitic uranium mine. Chem. Geol. 1999, 158, 81-103.

(20) Schofield, E. J.; Veeramani, H.; Sharp, J. O.; Suvorova, E.; Bernier-Latmani, R.; Mehta, A.; Stahlman, J.; Webb, S. M.; Clark, D. L.; Conradson, S. D.; Ilton, E. S.; Bargar, J. R. Structure of biogenic uraninite produced by Shewanella oneidensis strain MR-1. Environ. Sci. Technol. 2008, 42, 7898-7904.

(21) Hennig, C.; Ikeda-Ohno, A.; Emmerling, F.; Kraus, W.; Bernhard, G. Comparative investigation of the solution species $\mathrm{U}(\mathrm{CO} 3)(5)(6-)$ and the crystal structure of Na-6 $\mathrm{U}(\mathrm{CO} 3)(5)$ center dot $12 \mathrm{H}(2) \mathrm{O}$. Dalton Trans. 2010, 39, 3744-3750.

(22) Okubo, T.; Fukushima, S.; Itakura, M.; Oshima, K.; Longtonglang, A.; Teaumroong, N.; Mitsui, H.; Hattori, M.; Hattori, R.; Hattori, T.; Minamisawa, K. Genome analysis suggests that the soil oligotrophic bacterium Agromonas oligotrophica (Bradyrhizobium oligotrophicum) is a nitrogen-fixing symbiont of Aeschynomene indica. Appl. Environ. Microbiol. 2013, 79, 2542-2551.

(23) Ontiveros-Valencia, A.; Ilhan, Z. E.; Kang, D. W.; Rittmann, B.; Krajmalnik-Brown, R. Phylogenetic analysis of nitrate- and sulfatereducing bacteria in a hydrogen-fed biofilm. FEMS Microbiol. Ecol. 2013, 85, 158-167.

(24) Rosenzweig, N.; Bradeen, J. M.; Tu, Z. J.; McKay, S. J.; Kinkel, L. L. Rhizosphere bacterial communities associated with long-lived perennial prairie plants vary in diversity, composition, and structure. Can. J. Microbiol. 2013, 59, 494-502.

(25) Garrity, G. M. Bergey's Manual of Systematic Bacteriology, 2nd ed.; Springer: New York, 2005; Vol. 2.

(26) Dobbin, P. S.; Carter, J. P.; García-Salamanca San Juan, C.; von Hobe, M.; Powell, A. K.; Richardson, D. J. Dissimilatory Fe(III) reduction by Clostridium beijerinckii isolated from freshwater sediment using Fe(III) maltol enrichment. FEMS Microbiol. Lett. 1999, 176, 131-138.

(27) Li, H.; Peng, J.; Weber, K.; Zhu, Y. Phylogenetic diversity of $\mathrm{Fe}(\mathrm{III})$-reducing microorganisms in rice paddy soil: Enrichment cultures with different short-chain fatty acids as electron donors. J. Soils Sediments 2011, 11, 1234-1242.

(28) Tuhela, L.; Carlson, L.; Tuovinen, O. H. Biogeochemical transformations of $\mathrm{Fe}$ and $\mathrm{Mn}$ in oxic groundwater and well water environments. J. Environ. Sci. Health, Part A-Environ. Sci. Eng. Toxic Hazard. Subst. Control 1997, 32, 407-426.

(29) Tait, K.; Laverock, B.; Shaw, J.; Somerfield, P. J.; Widdicombe, $S$. Minor impact of ocean acidification to the composition of the active 
microbial community in an Arctic sediment. Environ. Microbiol. Rep. 2013, 5, 851-860.

(30) Loffler, F. E.; Yan, J.; Ritalahti, K. M.; Adrian, L.; Edwards, E. A.; Konstantinidis, K. T.; Muller, J. A.; Fullerton, H.; Zinder, S. H.; Spormann, A. M. Dehalococcoides mccartyi gen. nov., sp nov., obligately organohalide-respiring anaerobic bacteria relevant to halogen cycling and bioremediation, belong to a novel bacterial class, Dehalococcoidia classis nov., order Dehalococcoidales ord. nov and family Dehalococcoidaceae fam. nov., within the phylum Chloroflexi. Int. J. Syst. Evol. Microbiol. 2013, 63, 625-635.

(31) Yamada, T.; Sekiguchi, Y.; Hanada, S.; Imachi, H.; Ohashi, A.; Harada, H.; Kamagata, Y. Anaerolinea thermolimosa sp nov., Levilinea saccharolytica gen. nov., sp nov and Leptolinea tardivitalis gen. nov., so. nov., novel filamentous anaerobes, and description of the new classes Anaerolineae classis nov and Caldilineae classis nov in the bacterial phylum Chloroflexi. Int. J. Syst. Evol. Microbiol. 2006, 56, 1331-1340. 